\section{DERMATOGLIFSKI PROFIL I SOMATOTIP BRAZILSKIH KANUISTA}

\section{DERMATOGLYPHIC PROFILE AND SOMATOTYPE OF BRAZILIAN ATHLETES OF SPEED CANOEING}

\section{Ana Paula Soares de Sousa, Heros Ribeiro Ferreira ${ }^{1}$, Jefferson da Silva Novaes ${ }^{1} \&$ Jose Fernandes Filho ${ }^{1}$}

${ }^{1}$ Univercidade Federal do Rio de Janeiro, Laboratório de Biociência do Movimento Humano. Rio de Janeiro, $R J$.

Originalni naučni članak doi:10.5550/sgia.181401.se.sfn UDK: 797.112.012.1(81)

\section{SAŽETAK}

U fokusu ovog istraživanja bio je analizirati dermatoglifski profil $i$ somatotip brazilskih kanuista. Ova studija je opisno komparativnog karaktera i uključivala je uzorak od 60 kanuista u disciplini sprint, koji su bili podijeljeni u četiri grupe u skladu klasifikacije prema: $k a=$ visokih performansi kajaka, $K i=$ srednjeg učinka, $C a=$ visokih performansi kanua $i \mathrm{Ci}=$ srednji učinak kanua. $\mathrm{Za}$ utvrđivanje dermatoglifskog profila je korišten protokol prema Cummins $i$ Midlo, a $z a$ Primljeno: 03.11.2017. Odobreno: 21.06.2018.

Korespodencija: Ana Paula Soares de Sousa, Rio de Janeiro, Brasil anapdesousa@hotmail.com

Sportlogia 2018, 14 (1), 74-85. E-ISSN 1986-6119

utvrđivanje somatotipa protokol prema Heath i Carter. Statističke analize izvršene su testom Kruskal-Wallis $i$ Bonferroni testom. Što se tiče dermatoglifskog uzorka pokazala se dominantnost " $L$ " $i$ digitalna formula " $L>W$ ", a sportista mora posjedovati brzinu $i$ snagu, moć $i$ koordinaciju, jer su presudne za uspjeh kanuista u disciplini sprint. Nisu utvrđene značajne razlike u D10, SQTL, MESQTL i MDSQTL između grupa. Utvrđeno je da je kod kanuista izražen somatotip mezomorf, što upućuje na izuzetno jaku tjelesnu strukturu i nizak nivo tjelesne masti. Ali, pokazale su se statistički značajne razlike između grupa kada je reč o indeksu somatotipa. Studije kao što je ova imaju za cilj optimizaciju strategije za selekciju $i$ vođenje trenažnog procesa brazilskih elitnih sportista.

Ključne reči: genetski, sportski, performansi.

\title{
INTRODUCTION
}

The canoe is the oldest means of transport. Six thousand years ago it was used by North American Indians, Eskimos and others populations as a means of locomotion by rivers and lakes (Marchi \& Mezzadri, 2003). The first canoeing competitions were in the Berlin Olympics in 1936, through speed mode, since then remained on the Olympic stage. Practice the speed canoeing in lakes (calm waters) with canoes $(\mathrm{C})$ and kayaks $(\mathrm{K})$. 
It is worth mentioning, although this sport is not considered popular in the country, Brazilian speed canoeing has achieved unpublished results in recent years, among them gold medal in the world championship of Germany

To increase the qualification of the sport, coaches seek possible explanations for scientific rationale for the relationship between sport, physical type, athletic performance and genetic, morphological, physiological, psychological, environmental factors, among others (Fernandes Filho, Dantas Moreira, \& Roquetti Fernandes, 2006).

According to Fernandes Filho et al. (2006), the development of a talented sportsman is mutual result of genetic endowment and the environment. In other words, Borin, Padovani, Aragon, and Gonçalves (2012) points out that the performance of an athlete is determined by the capabilities of complex, innate and acquired. Medina and Fernandes Filho (2002) concludes that the finding of these features can benefit the athlete's performance and help select appropriate training methods and targeted to motor skills inherent to sport.

Regarding high yield, Zary (2008) and Sousa, Ferreira, and Fernandes Filho (2016) observed that athletes of this level could serve as a standard to be followed by those who practice this sport, determining model parameters and characteristics, since successful athletes must submit a favorable genetic profile to the specificities of each modality. Stands out among these genetic markers, the dermatoglyphic, consisting of a tool to assessment and interpretation of fingerprints of 10 fingers and identification of intrinsic physical qualities to the individual and the sport (Abramova, Nikitina, Izaak, \& Kochetkova, 2000). Most authors distinguish three groups of drawings: Arch, Loop and Whorl.

Figure 1- Drawing types of Fingerprints

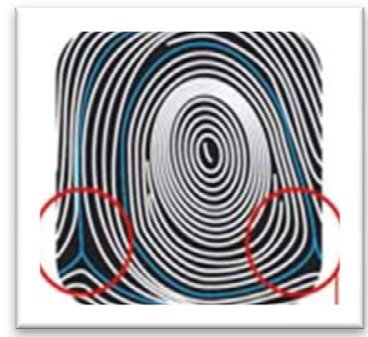

$\operatorname{Arch}(\mathbf{A})$

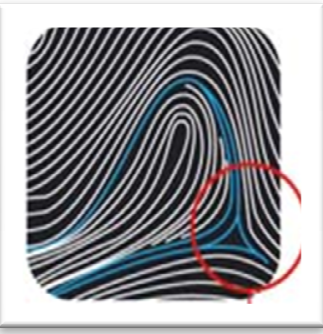

$\operatorname{Loop}(\mathbf{L})$

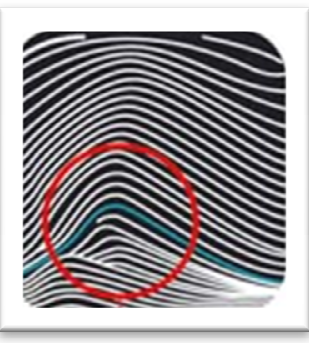

Whorl (W)

Source: Fernandes Filho (2009) 
The researchers established an association of fingerprints with physical qualities:

- Speed and explosive power: loops increased (> 7), decreased whorls. $(<3)$, and increased presence of the arches.

- Aerobic capacity, endurance and combination of complex motor activities: lower arches (to 0$)$ and loops $(<6)$, increased whorls $(>4)$.

Many studies were conducted to trace the dermatoglyphic and somatotypic profile Brazilian high-level athletes in various modalities in an attempt to get them to maximum performance with a genetic profile and adequacy of the guidance according by the requirements inherent in each modality training. (Abad-Colil, Hernández-Mosqueira, \& Fernandes Filho, 2017; Aitken \& Jenkins, 1998; Castanhede, Dantas, \& Fernandes Filho, 2003; Dantas \& Fernandes Filho, 2004; Fernandes Filho, Carvalho, \& Novaes, 2005; Fernandes Filho, Silva Dantas, Albergaria, \& Fernandes, 2004; Ferreira, Barbosa, \& Fernandes Filho, 2008; Fonseca, Silva Dantas, \& Fernandes, 2008; Gobbo et al., 2002; Medina \& Fernandes Filho, 2002; Paz et al., 2013; Takehara, 2016).

The morphological configuration becomes very important for the improvement of these motor skills and characterization of a high performance athlete. According Heath and Carter, somatotype is the method as a sequence of three numerals, always in the same order, where each represents a physical component, describing the variations of the individual with respect to morphology and composition (Castanhede et al., 2003; Rocha, Fernandes, \& Filho, 2013). Tubino and DaCosta (2006) emphasizes the importance of the correlation between body structure and performance capabilities.

Gobbo et al. (2002) highlights the lack of research on canoeing in Brazil. Thus, due the dearth of information about this sport, justifies the need for scientific research to assist in the selection and planning training of athletes. Therefore, the aim of this study was to evaluate the dermatoglyphic profile and somatotype of Brazilian athletes of speed canoeing, of canoe and of kayak. This analysis will allow a better exploitation of the sport, allowing guide the training methodology for the development of the athlete's performance in both the initiation and with high yield.

\section{METHODS}

This study involved a comparative descriptive character sample of $n=60$ male athletes in speed canoeing, and of these $n=31$ athletes vying for evidence in canoe $(C)$ and $n$ 
$=29$ in kayaks $(\mathrm{K})$. Of the total, $\mathrm{n}=26(\mathrm{n}=15 \mathrm{Ca}$ and $\mathrm{Ka} \mathrm{n}=11)$ subjects were classified high yield medalists, champions of Pan American, world championships and / or Olympics and $\mathrm{n}=34(\mathrm{C}=16$ and $\mathrm{K} \mathrm{n}=18)$ intermediate athletes with medals in national championships. Both levels with over 5 years of training experience.

The gather of fingerprints was performed using a Verifier 320 LC Cross Match ${ }^{\circledR}$ scanner used according to the protocol dermatoglyphic described by Cummins and Midlo (Fernandes Filho, 2009). The distal phalanges of the fingers were pressed on the digital player performing a rotational motion and then identified the following Dermatoglyphic Drawings: Arch (A), Loop (L) and Whorl (W) and the following dermatoglyphic indices:

-Type of drawings of each finger of each hand (MET and MDT);

-The amount of these types of drawings in 10 fingers (D10),

-The sum of total number of lines of 10 fingers (SQTL).

The analysis of the dermatoglyphic characteristics was held for three (3) researches trained in Bioscience Laboratory of Human Movement of Federal University of Rio de Janeiro.

Somatotype indices were obtained from the protocol Heath \& Carter. It was used a measure of Subscapular, triceps, supraspinatus and medial calf bone diameters, weight, height, circumference of right arm contracted corrected, corrected perimeter of the right leg, and bone diameter of femoral and humeral (Fernandes Filho, 2010). The following instruments were used: bioimpedance scale InBody R-20, a stadiometer, a caliper, an anthropometric tape and a caliper of Sanny brand. After registration of the data of each component was calculated.

Data collection was approved by the Brazilian Canoe Confederation (CBCa, in Portuguese) and his current president. Written free and informed consent forms were obtained from all the athletes.

In conducting the statistical analysis, we used the Statistical Package for the Social Sciences (SPSS 16.0) .The descriptive analyzes were performed considering the mean and standard deviation statistical parameters.

Data normality was verified by the Shapiro-Wilk test, which identified that the results were nonparametric for all variables. To carry out the comparisons between groups, we used the Kruskal-Wallis test, which verified if hypotheses of averages of group presented differences statistically significant. Then, was held the Bonferroni test, which corrected the value of "p" avoiding the tendency of the error type I. All these procedures were treated with significance level $(\mathrm{p}<0.05)$. 


\section{RESULTS}

By observing the results described in Table 1, it can be seen in relation to the Age of group athletes intermediate performance of canoe ( $\mathrm{Ci}$ ) has a lower mean than everyone else, but when making the comparison was identified a significant difference only between this group and the intermediate performance of kayak (Ki) (sig. = 0.004).

The results concern the Body Mass demonstrate again that the Ci group had a lower mean, but this time the comparison showed significant differences with all other groups, High performance of kayak (Ka) and intermediate performance of kayak (Ki), High performance of canoe $(\mathrm{Ca})$ : $\mathrm{Ci} \times \mathrm{Ka}(\mathrm{p}=0.023) \mathrm{Ci} \times \mathrm{Ki}(\mathrm{p}=0.007)$ and $\mathrm{CixCa}(\mathrm{p}=0.005)$.

As for height, it was found that the $\mathrm{Ci}$ group showed a lower mean than all other groups, but was not identified significant differences $(p=0.318)$.

Table 1- Descriptive results relating to Age, Height and Body Mass of Brazilian athletes speed canoeing.

\begin{tabular}{lllll}
\hline \multirow{2}{*}{ Variable } & \multicolumn{4}{c}{ Groups $(\boldsymbol{\mu} \pm \mathbf{s})$} \\
\cline { 2 - 5 } & $\mathbf{K a}(\mathbf{n}=\mathbf{1 6})$ & $\mathbf{K i}(\mathbf{n}=\mathbf{1 8})$ & $\mathbf{C a}(\mathbf{n}=\mathbf{1 5})$ & $\mathbf{C i}(\mathbf{n}=\mathbf{1 1})$ \\
\hline Age $($ years)* & $22,4 \pm 6,5$ & $21 \pm 8,5$ & $22,6 \pm 4,5$ & $18,2 \pm 34$ \\
Body Mass $(\mathbf{k g}) *$ & $75,5 \pm 11,3$ & $76,7 \pm 9,8$ & $77,6 \pm 8,1$ & $63,8 \pm 9,9$ \\
Height $(\mathbf{c m})$ & $178,2 \pm 7,1$ & $175,5 \pm 3,8$ & $176,6 \pm 5,5$ & $172,7 \pm 6,8$ \\
\hline
\end{tabular}

$\boldsymbol{\mu}=$ mean; $\mathbf{s}=$ standard deviation; ${ }^{*}$ significant difference between groups

The study Gobbo et al. (2002) the mean age of male Brazilian athletes of speed canoeing of 2002 was $19.5 \pm 2.5$ years, mean body mass was $79.9 \pm 5.7 \mathrm{~kg}$ and the height was of $182.6 \pm 4.8 \mathrm{~cm}$.

The descriptive results of the qualitative and quantitative characteristics of dermatoglyphic profile of Brazilian athletes in speed canoeing, of canoe and kayak, and of high and intermediate, are showed in Tables 2, 3 and 4.

It was assigned a value to each type of drawing of each finger: Arch=0, Loop=1, Whorl=2:The type of drawing of a particular group is classified based on mean values: lower than 0,5 will be considered as $\operatorname{arch}(\mathrm{A})$, between 0,51 and 1,49 loops (L) and upper and equal to 1,5 whorls $(\mathrm{W})$. 
Table 2 - Type classification of fingerprints of each finger of Brazilian athletes speed canoeing.

Table 2 - Type classification of fingerprints of each finger of Brazilian athletes speed canoeing.

\begin{tabular}{|c|c|c|c|c|c|c|c|c|c|c|c|}
\hline & & MET1 & MET2 & MET3 & MET4 & MET5 & MDT1 & MDT2 & MDT3 & MDT4 & MDT5 \\
\hline \multirow{2}{*}{$\mathbf{K a}$} & $\mu \pm s$ & $1,50 \pm 0,5$ & $1,25 \pm 0,4$ & $1,13 \pm 0,3$ & $1,38 \pm 0,5$ & $1,13 \pm 0,3$ & $1,50 \pm 0,5$ & $1,49 \pm 0,5$ & $1,19 \pm 0,4$ & $1,38 \pm 0,5$ & $1,27 \pm 0,5$ \\
\hline & DRAWING & $\mathbf{W}$ & $\mathbf{L}$ & $\mathbf{L}$ & $\mathbf{L}$ & $\mathbf{L}$ & $\mathbf{W}$ & $\mathbf{L}$ & $\mathbf{L}$ & $\mathbf{L}$ & $\mathbf{L}$ \\
\hline \multirow{2}{*}{$\mathbf{K i}$} & $\mu \pm \mathrm{s}$ & $1,38 \pm 0,5$ & $1,11 \pm 0,6$ & $1,11 \pm 0,5$ & $1,33 \pm 0,5$ & $1,0 \pm 0,0$ & $1,44 \pm 0,5$ & $1,38 \pm 0,5$ & $1,33 \pm 0,5$ & $1,50 \pm 0,5$ & $1,00 \pm 0,0$ \\
\hline & DRAWING & $\mathbf{L}$ & $\mathbf{L}$ & $\mathbf{L}$ & $\mathbf{L}$ & $\mathbf{L}$ & $\mathbf{L}$ & $\mathbf{L}$ & $\mathbf{L}$ & $\mathbf{W}$ & $\mathbf{L}$ \\
\hline \multirow{2}{*}{$\mathrm{Ca}$} & $\mu \pm \mathrm{s}$ & $1,27 \pm 0,5$ & $1,36 \pm 0,5$ & $1,29 \pm 0,5$ & $1,43 \pm 0,5$ & $1,0 \pm 0,0$ & $1,33 \pm 0,5$ & $1,40 \pm 0,5$ & $1,29 \pm 0,5$ & $1,47 \pm 0,5$ & $1,13 \pm 0,4$ \\
\hline & DRAWING & $\mathbf{L}$ & $\mathbf{L}$ & $\mathbf{L}$ & $\mathbf{L}$ & $\mathbf{L}$ & $\mathbf{L}$ & $\mathbf{L}$ & $\mathbf{L}$ & $\mathbf{L}$ & $\mathbf{L}$ \\
\hline \multirow{2}{*}{$\mathrm{Ci}$} & $\mu \pm \mathrm{s}$ & $1,45 \pm 0,5$ & $1,00 \pm 0,6$ & $1,18 \pm 0,4$ & $1,45 \pm 0,5$ & $1,18 \pm 0,4$ & $1,45 \pm 0,5$ & $1,18 \pm 0,4$ & $1,18 \pm 0,4$ & $1,45 \pm 0,5$ & $1,45 \pm 0,5$ \\
\hline & DRAWING & $\mathbf{L}$ & $\mathbf{L}$ & $\mathbf{L}$ & $\mathbf{L}$ & $\mathbf{L}$ & $\mathbf{L}$ & $\mathbf{L}$ & $\mathbf{L}$ & $\mathbf{L}$ & $\mathbf{L}$ \\
\hline
\end{tabular}

MET $=$ Type of design of each finger of the left hand (1st to 5th finger).); MED= Type of design of each finger of the right hand (1st to 5th finger).; $\mathbf{L}=$ loop; $\mathbf{W}=$ whorl.

The sample showed similar types compared the five fingers of one hand with the other when it comes groups of high yield, Ca and Ka. According to Fernandes Filho (2009) in high yield there is a tendency that the results show a complete overlap of the drawings, setting up of the "mirror".

Table 3 shows the low occurrence of arcs (A) and a predominance of loop (L). As explained Del Vecchio and Gonçalves (2011) and Santos, Moreira Silva Dantas, and Fernandes Filho (2008), in high yield there is a tendency to decrease the arches (A) and increase of complex drawings.

Table 3 - Frequency distribution of types of design and digital formulas of Brazilian athletes in speed canoeing

\begin{tabular}{cllllllllllll}
\hline \multirow{2}{*}{ Groups } & \multicolumn{10}{c}{ Drawing (\%) } & \multicolumn{10}{c}{ Digital Formulas (\%) } \\
\cline { 2 - 14 } & $\mathbf{A}$ & $\mathbf{L}$ & $\mathbf{W}$ & $\mathbf{A L}$ & $\mathbf{A W}$ & $\mathbf{A L W}$ & $\mathbf{1 0 W}$ & $\mathbf{L}>\mathbf{W}$ & $\mathbf{W}>\mathbf{L}$ & $\mathbf{1 0 L}$ & $\mathbf{L}=\mathbf{W}$ \\
\hline $\mathbf{K a}$ & 1,8 & 66,4 & 31,8 & 18,2 & 0 & 0 & 0 & 36,4 & 18,2 & 18,2 & 9,1 \\
$\mathbf{K i}$ & 5,6 & 68,3 & 26,1 & 0 & 0 & 38,9 & 0 & 16,7 & 5,6 & 16,7 & 22 \\
$\mathbf{C a}$ & 2,7 & 68,7 & 28,7 & 13,3 & 0 & 0 & 0 & 40 & 20 & 20 & 6,7 \\
$\mathbf{C i}$ & 0,6 & 71,3 & 28,1 & 0 & 0 & 6,2 & 0 & 50 & 12,5 & 25 & 6,2 \\
\hline
\end{tabular}


$\mathbf{A}=\operatorname{arch} ; \mathbf{L}=$ loop; $\mathbf{W}=$ whorl; $\mathbf{A L}=$ presence of Arcs and Loops; $\mathbf{A W}=$ Presence of Arcs and Whorls; $\mathbf{A L W}=$ Presence of Arcs, Loops and Whorls; $\mathbf{1 0 W}=$ Presence of 10 Whorls; $\mathbf{L}>\mathbf{W}=$ Presence of Loop and Whorl with predominant than Loop; $\mathbf{W}>\mathbf{L}=$ Presence of Whorl and Loop with predominant than Whorl; 10L $=$ Presence of 10 Whorls; $\mathbf{L}=\mathbf{W}$ Equal amount of Loops e Whorls.

Despite the differences presented in the Table above, there was no statistical significance when comparing the mean values of Groups of drawings dermatoglyphic $\mathrm{A}(\mathrm{p}=$ 0.93), L ( $\mathrm{p}=0.899)$ and $\mathrm{W}(\mathrm{p}=0.996)$.

Table 4- Mean values and comparing the D10, SQTL, MESQTL MDSQTL and Brazilian athletes in speed canoeing.

\begin{tabular}{cccccc}
\hline VARIABLES & $\mathbf{K a}$ & $\mathbf{K i}$ & $\mathbf{C a}$ & $\mathbf{C i}$ & Kruskal-Wallis \\
\cline { 2 - 6 } & $\boldsymbol{\mu} \pm \mathbf{S}$ & $\boldsymbol{\mu} \pm \mathbf{S}$ & $\boldsymbol{\mu} \pm \mathbf{S}$ & $\boldsymbol{\mu} \pm \mathbf{S}$ & Sig. \\
\hline D 10 & $12,8 \pm 2,8$ & $12,6 \pm 2,5$ & $12,6 \pm 3,4$ & $13 \pm 3,6$ & 0,934 \\
SQTL & $139,2 \pm 26,9$ & $141,3 \pm 39,6$ & $144,8 \pm 45,8$ & $128,7 \pm 4,6$ & 0,708 \\
MESQTL & $69,7 \pm 12,9$ & $69,6 \pm 20,5$ & $70,9 \pm 24,8$ & $62,3 \pm 23,3$ & 0,576 \\
MDSQTL & $66,5 \pm 16,1$ & $71,8 \pm 19,6$ & $73,9 \pm 21,5$ & $66,4 \pm 22,9$ & 0,794 \\
\hline
\end{tabular}

D10 = number of drawings of the ten fingers of the hands; SQTL = Sum of the Total Number of Lines ; MESQTL $=$ Sum of the Total Number of Lines Left Hand MDSQTL $=$ Sum of the Total Number of Lines right Hand; $\boldsymbol{\mu}=$ Mean; $\mathbf{s}=$ standard deviation;

It is possible to observe in Table 3 and 4, which athletes of both modalities, kayak and canoe, showed high values in the indices of D10 and LQTS. Abramova, Nikitina, and Ozolin (1995) reported that in high performance, high number of D10, the absence of arcs (A), the greater amount of complex drawing ( $\mathrm{L}$ and $\mathrm{W}$ ) and a high value for SQTL featuring sports of speed and strength, power and coordination as well as canoeing.

It also indicated a predominance of digital formula " $\mathrm{L}>\mathrm{W}$ " in all groups, and can say that they have a predisposition to prolonged speed activities, corroborating the study of Nakamura (2004), who also found this ratio in results in speed canoeing. However, this difference was not statistically significant. 
Table 5- Mean values and comparison of somatotype indices of Brazilian athletes in speed canoeing

\begin{tabular}{lllllll}
\hline \multirow{2}{\text{ÍNDex}}{} & $\mathbf{K a}$ & $\mathbf{K i}$ & $\mathbf{C a}$ & $\mathbf{C i}$ & Kruskal- \\
\cline { 2 - 6 } & $\boldsymbol{\mu} \pm \mathbf{S}$ & $\boldsymbol{\mu} \pm \mathbf{s}$ & $\boldsymbol{\mu} \pm \mathbf{s}$ & $\boldsymbol{\mu} \pm \mathbf{s}$ & Sig. \\
\hline ENDOMORPH* & $2,44 \pm 1,87$ & $2,51 \pm 1,10^{* *}$ & $1,86 \pm 0,67$ & $1,66 \pm 0,44^{* *}$ & 0,027 \\
MESOMORPH* $^{*}$ & $5,59 \pm 1,13$ & $5,73 \pm 1,09$ & $6,35 \pm 1,03^{* *}$ & $5,01 \pm 0,65^{* *}$ & 0,019 \\
ECTOMORPH* $^{*}$ & $2,42 \pm 1,04$ & $1,91 \pm 1,24$ & $1,74 \pm 0,62^{* *}$ & $3,19 \pm 0,98^{* *}$ & 0,007 \\
\hline
\end{tabular}

$\mu=$ Mean; s = standard deviation; ; * significant difference between Groups: ** significant differences among themselves by the Bonferroni test $(\alpha=5 \%)$

Table 6- Frequency distribution of the somatotype classification of Brazilian athletes in speed canoeing

\begin{tabular}{clcc}
\hline GROUPS & SOMATOTYPE & FREOUENCY & PERCENTAGE \\
\hline \multirow{4}{*}{ Ka } & Ecto-Mesomorph & 1 & 6,2 \\
& Endo-Mesomorph & 1 & 6,2 \\
& Meso-Endomorph & 2 & 12,5 \\
& Balanced Mesomorph & 3 & 18,8 \\
& Meso-Ectomorph & 9 & 56,2 \\
\hline \multirow{6}{*}{ Ki } & Total & 16 & $100 \%$ \\
& Balanced Mesomorph & 1 & 5,6 \\
& Ecto-Mesomorph & 2 & 11,1 \\
& Mesomorph Endomorph & 2 & 11,1 \\
& Meso-Ectomorph & 3 & 16,7 \\
& Meso-Endomorph & 10 & 55,6 \\
\hline \multirow{2}{*}{ Ca } & Total & 18 & $100 \%$ \\
& Meso-Endomorp & 4 & 26,7 \\
& Meso-Ectomorph & 5 & 33,3 \\
& Balanced Mesomorph & 6 & 40 \\
\hline \multirow{2}{*}{ Ci } & Total & 15 & $100,0 \%$ \\
& Meso-Endomorph & 2 & 18,2 \\
& Balanced Mesomorph & 2 & 18,2 \\
& Mesomorph Ectomorph & 3 & 27,3 \\
& Meso-Ectomorph & 4 & 36,4 \\
\hline & Total & 11 & $100,0 \%$ \\
\hline
\end{tabular}

It can be seen in Table 6, that groups of $\mathrm{Ka}$ and $\mathrm{Ci}$ had a mean somatotype MesoEctomorph, showing a relative musculoskeletal development and greater volume of muscle and bone. The group $\mathrm{Ca}$ presented balanced mesomorph that also represents high muscleskeletal development, large bone diameters, large muscle volume and large joints. In turn, the 
group $\mathrm{Ki}$ had a mean of meso-endomorphic somatotype, which represents a moderate musculoskeletal development.

Thus, corroborating with the study of Machado (2010) and Lima, Sigwalt, Rech, and Petroski (2008) who find Mesomorph as the mean of somatotype of elite athlete's modality requiring efforts predominantly in muscle strength and power.

\section{CONCLUSION}

Although this modality, speed boating, can be practiced in calm waters requires an extremely fatiguing effort of strength and muscle power, developing the processes of muscle hypertrophy, as evidenced in the classification of somatotype, with the predominance of the mesomorph component, an extremely strong structure and low levels of body fat.

The results of this study also showed dermatoglyphic characteristics of speed kayaking athletes of different vessels, kayaks and canoes. Knowing the profile of these highperformance athletes determined parameters and model characteristics, and enables the aggregation of dermatoglyphics as markers of genetic potential, plus an assessment protocol and parameters for orientation training for sports according to their specificities.

Worth noting, that Brazil has achieved impressive results, but set up a profile for this sporty is a necessity, since in many variables the results were not homogeneous. It is pertinent to emphasize a thought researcher Fernandes Filho "[...] is not the athlete who chooses the sport, and yes, the sport who chooses the athlete." (Fonseca, Dantas, Roquetti Fernandes, \& Fernandes Filho, 2008).

Can conclude that research like this, to collaborate as references for future research. Nevertheless, future studies on the identification of the genetic profile of this modality are still necessary to provide a greater potential of success in this sport.

\section{REFERENCES}

Abad-Colil, F., Hernández-Mosqueira, C., \& Fernandes Filho, J. (2017). Dermatoglifia, fuerza máxima y rendimiento ergométrico en seleccionados chilenos de remo. Revista Horizonte: Ciencias de la actividad física, 6(1), 7-13.

Abramova, T., Nikitina, T., Izaak, S., \& Kochetkova, N. (2000). Asymmetry of signs of finger dermatoglyphics, physical potential and physical qualities of a man. Morfologiia (Saint Petersburg, Russia), 118(5), 56-59. PMid:11452431

Sousa, A.P., Ferreira, H.R., Novaes, J.d.S, \& Filho, J.F.(2018). Dermatoglifski profil i somatotip brazilskih kanuista. Sportlogia, 14(1), 74-85. doi:10.5550/sgia.181401.se.sfn 
Abramova, T., Nikitina, T., \& Ozolin, N. (1995). Possibilidades de utilização das impressões dermatoglíficas na seleção desportiva. Teoria e prática da cultura física, 3, 10-15.

Aitken, D. A., \& Jenkins, D. G. (1998). Anthropometric-based selection and sprint kayak training in children. Journal of sports sciences, 16(6), 539-543. https://doi.org/10.1080/026404198366506

PMid:9756258

Borin, J., Padovani, C., Aragon, F., \& Gonçalves, A. (2012). Dermatoglyphics in Sports Sciences: Understanding the distribution of quantitative indicators in non-athletes and athletes of basketball according to their performance. Revista Andaluza de Medicina del Deporte, 5(3), 99-104.

https://doi.org/10.1016/S1888-7546(12)70015-1

Castanhede, A. L., Dantas, P. M., \& Fernandes Filho, J. (2003). Dermatoglyphic and somatotype profile of male soccer athletes of high performance in Rio de Janeiro-

Brazil. Fitness \& Performance Journal (Online Edition), 2, 234-239. https://doi.org/10.3900/fpj.2.4.234.e

https://doi.org/10.3900/fpj.2.4.234.p

https://doi.org/10.3900/fpj.2.4.234.s

Dantas, P. M. S., \& Fernandes Filho, J. (2004). Dermatoglyphia in high performance brazilian futsal. Fitness \& Performance Journal (Online Edition).

Del Vecchio, F., \& Gonçalves, A. (2011). Dermatoglifos como indicadores biológicos del rendimiento deportivo. Revista Andaluza de medicina del deporte, 4(1), 38-46.

Fernandes Filho, J. (2009). Dermatoglifia no esporte e na saúde Rio de janeiro: Rio de Janeiro.

Fernandes Filho, J. (2010). A prática da avaliação física: testes, medidas, avaliação física em escolares, atletas e academias de ginástica.

Fernandes Filho, J., Carvalho, E., \& Novaes, J. S. (2005). Perfis dermatoglífico, somatotípico e fisiológico dos atletas de alto rendimento, participantes de corrida de resistência, no Rio de Janeiro Fitness \& Performance Journal (Online Edition).

Fernandes Filho, J., Dantas Moreira, P., \& Roquetti Fernandes, P. (2006). Genética e treinamento esportivo: o uso prático da dermatoglifia. DaCosta, L.(Org.) Atlas do Esporte no Brasil. Rio de Janeiro: CONFEF.

Fernandes Filho, J., Silva Dantas, P., Albergaria, M., \& Fernandes, P. (2004). Somatotype and dermatoglyphics in high income of Brazilian volleyball, futsal, basketball and handball adult. Paper presented at the Pre-Olympic Congress.

Sousa, A.P., Ferreira, H.R., Novaes, J.d.S, \& Filho, J.F.(2018). Dermatoglifski profil i somatotip brazilskih kanuista. Sportlogia, 14(1), 74-85. doi:10.5550/sgia.181401.se.sfn 
Ferreira, H., Barbosa, F., \& Fernandes Filho, J. (2008). Correlação entre níveis de preensão manual e dermatóglifos dos atletas da seletiva olímpica de canoagem slalom para Pequin 2008. EF y Deportes revista digital.

Fonseca, C. L. T., Dantas, P. M. S., Roquetti Fernandes, P., \& Fernandes Filho, J. (2008). Perfil dermatoglífico, somatotípico e da força explosiva de atletas da seleção brasileira de voleibol feminino. Fitness \& Performance Journal, 7(1).

Gobbo, L. A., Papst, R. R., Carvalho, F. O., Souza, C. F., Cuattrin, S. A., \& Cyrino, E. S. (2002). Perfil antropométrico da seleçäo brasileira de canoagem. Rev. bras. ciênc. mov, 10(1), 7-12.

Lima, L. R. A., Sigwalt, A. R., Rech, C. R., \& Petroski, E. L. (2008). Somatotipo e composição corporal de atletas feminino de pólo aquático do Brasil. Journal of Physical Education, 18(2), 191-198.

Machado, R. J. d. A. M. (2010). Estudo cineantropométrico de jovens canoistas ibéricos. Paper presented at the Estudo cineantropométrico de jovens canoistas ibéricos.

Marchi, K. B., \& Mezzadri, F. M. (2003). História da Canoagem e do Rafting. ANPUH-XXII.

Medina, M. F., \& Fernandes Filho, J. (2002). Identificação dos perfis genético e somatotípico que caracterizam atletas de voleibol masculino adulto de alto rendimento no Brasil. Fitness \& Performance Journal, 1(4), 12-19.

Paz, C. R., Montenegro, R. C., Barbosa, E. d. L., Montenegro-Neto, A. N., Lucena, S. M. d., Araújo Filho, V. S., . . . Fernandes Filho, J. (2013). Frequency of anaeronbic power among brazilians based on dermatoglyphics and R577X polymorphism of the ACTN3 protein SportLogia, 9(1).

Rocha, L., Fernandes, P., \& Filho, J. F. (2013). Motor features, dermatoglyphic and EEG periods of girls in pre and post menarche. Sportlogia, 9(1), p34-45. https://doi.org/10.5550/sgia.130901.en.005R

Nakamura FY, Borges TO, Sales OR, Cyrino ES, Kokubun E. (2004). Energetic cost estimation and contribution of different metabolic pathways in speed kayaking. Revista Brasileira de Medicina do Esporte.;10(2):70-7. https://doi.org/10.1590/S1517-86922004000200002

Santos, L. C. d., Moreira Silva Dantas, P., \& Fernandes Filho, J. (2008). Características genotípicas e fenotípicas em atletas velocistas. Motricidade, 4(1). https://doi.org/10.6063/motricidade.4(1).523 
Sousa, A., Ferreira, H., \& Fernandes Filho, J. (2016). Dermatoglyphic Profile and Hand Grip Strength of the Finalists Athletes in the Brazilian Paracanoe Championship Journal of Exercise Physiology online, 19 50-56.

Takehara, J. C. (2016). Perfil dermatoglífico, somatotípico e fisiológico de atletas de elite do rafting.

Tubino, M. G., \& DaCosta, L. (2006). Treinamento Esportivo. Atlas do Esporte no Brasil, 133-115.

Zary, J. C. F. (2008). Identificação do perfil dermatoglífico e somatotípico dos atletas de voleibol masculino adulto, juvenil e infanto-juvenil, de alto rendimeto no Brasil. Revista Brasileira de Ciência e Movimento, 15(1), 53-60.

\section{Summary}

The focus of this study was analyze dermatoglyphic profile and somatotype of Brazilian athletes of speed canoeing. This study is descriptive comparative and involved a sample of $n$ $=60$ male athletes of canoeing speed, divided into four groups according by the proof and yield classification: $k a=$ high performance of kayak, Ki=intermediate performance of kayak, $\mathrm{Ca}=$ high performance of canoe and Ci=intermediate performance of canoe. For dermatoglyphic was used the protocol of Cummins and Midlo, and to somatotype protocol of Heath \& Carter. Statistical analyzes were performed using Kruskal-Wallis test and Bonferroni test. Regarding the dermatoglyphic sample showed a predominance of " $L$ " and the digital formula " $L>W^{\prime}$, featuring athletes of speed and strength, power and coordination as well as is necessary in canoeing. No significant differences in D10, SQTL, MESQTL and MDSQTL between groups. The mean of somatotype was the mesomorph, featuring athletes with extremely strong structure and low levels of body fat. It showed statistically significant differences between the groups when it came somatotype index. Studies such as this aims to optimize strategies for selection and guidance training of Brazilian elite athletes.

Key words: genetics, sport, performance

Primljeno: 03.11.2017.

Odobreno: 21.06.2018.

Korespodencija: Ana Paula Soares de Sousa,

Rio de Janeiro, Brasil anapdesousa@hotmail.com 